\title{
The Impact of Acquisition on Bentoel Internasional Investama Corporation Financial Performance
}

\author{
Wiwiek Mardawiyah Daryanto ${ }^{1}$,Bramastra Purnomosidhi ${ }^{2}$, \\ Sarah Khairannisa ${ }^{3 *}$ \\ ${ }^{1}$ Sekolah Tinggi Manajemen IPMI, Jakarta 12750, Indonesia \\ ${ }^{2,3}$ School of Business and Management, Institut Teknologi Bandung, Jakarta 12950, Indonesia
}

\begin{abstract}
A B S T R A C T
Indonesia Tobacco Industry is one of the most prosperous business in the world, globalization made company across the globe racing to acquire tobacco company. Indonesian investment climate allows acquisition conduct by a foreign company in this sector. This study based on the acquisition of PT. Bentoel Internasional Investama (RMBA) by a foreign company (British American Tobacco) in 2010, the data was collected from the annual report of RMBA during 20062015. Four accounting ratio were applied to test the significant change in the financial performance of RMBA five years before and five years after the acquisition. There is a significant difference in the financial performance of the RMBA between pre and post-acquisition. The significant difference can be used as an input to improve RMBA financial performance. This study provides an empirical analysis before and after acquisition that can be served for a future strategy on acquisition tobacco company in Indonesia.
\end{abstract}

ART I CLE IN F O

Keywords:

Acquisition,

Tobacco Company,

Financial Performance,

Investment,

Indonesia
${ }^{*}$ Corresponding Author E-mail: sarah.khairannisa@sbm-itb.ac.id permits unrestricted use, distribution, and reproduction in any medium, provided the original work is properly cited.

\section{INTRODUCTION}

Tobacco industry grows rapidly in South East Asia especially in Indonesia, the tobacco company always become a symbol of wealth and prosperity that because of strong and steady demand for a cigarette. This can be interpreted as sustain business, constant revenue, and high-profit result. The tobacco industry commonly has greater economic leverage than any other industry. The impact is directly giving a price per shares of tobacco company relatively high; this is why many corporations want to have tobacco company on their hand. According to Suparwoto (1990:4), there is three-way to merged company: Consolidation, Mergers, and Acquisitions.

Commonly to penetrate tobacco industry in Indonesia foreign company prefer acquisition which means to take over ownership or control 
over of shares or asset of an enterprise by another company, and in the event of either acquired or expropriated company still exist as a separate legal entity (Moin, 2003). The impact of this act will directly hit every sector from the employee, asset, equity, liability, etc. This study used PT. Bentoel Internasional Investama (RMBA) as a company that acquired by British American Tobacco (BAT) in 2010. This acquisition is made BAT as a controlling shareholder of this company by buying $51 \%$ of their share. The conduct between two company will give impact on RMBA directly on financial performance.

The purpose of this study is to measure of a successful acquisition as a strategy activity can be seen both through the achievement of market share and from the financial ratios include liquidity ratio, solvency ratio, ratio activity, and profitability ratios. From the measurement of those ratios that can answer how the acquisition made an impact on the financial performance of RMBA in the period five years before (pre-) and five years after (post-) acquisition.

\section{LITERATURE REVIEW}

\section{Acquisition}

Nakamura (2005) said that an acquisition takes place when a company attains all or part of the target company's assets and the target remains as a legal entity after the transaction whereas in a share acquisition a company buys a certain share of stocks in the target company in order to influence the management of the target company.

Majority of the studies has focused on the preand post-acquisition performance of the company involved, often with rather conflicting results. Rao and Sanker (1997), for instance, found a positive effect on the liquidity, leverage, and profitability of the acquirer firms. Other studies have also shown a positive impact on firms' performance (Hitt, Harrison \& Best, 1998; Chevalier, 2004) but several other studies have found that Merger and Acquisition either have no effect or are detrimental to firm's post-acquisition performance.

\section{Financial Ratio Analysis}

\section{ROE (Return on Equity)}

Return on Equity is a financial ratio that how much profit a company earned compared to the total amount of shareholder equity invested or found on the balance sheet. ROE is what the shareholders look in return for their investment. A business that has a high return on equity is more likely to be one that is capable of generating cash internally. There is a statement that the higher the ROE the better the company is in terms of profit generation. Khrawish (2011) said that ROE is the ratio of Net Income after Taxes divided by total equity capital. It represents the rate of return earned on the funds invested in the company by its stockholders. ROE reflects how effectively firm management is using shareholder funds. Thus, it can be deduced from the above statement that the better the ROE the more effective the management in utilizing the shareholders capital.

$$
\text { Return on Equity }=\frac{\text { Net Income }}{\text { Shareholders Equity }}
$$

\section{ROA (Return on Assets)}

Return on Assets is another major ratio that indicates the profitability of a company. It is a ratio of Income to its total asset (Khrawish, 2011). It measures the ability of the company management to generate income by utilizing company assets at their disposal. It shows how efficiently the resources of the company are used to generate income. In other words, further indicates the efficiency of the management of a company in generating net income from all the resources of the institution (Khrawish, 2011). There is a statement that a higher ROA shows the company is more efficient in using its resources.

$$
\text { Return on Assets }=\frac{\text { Net Income }}{\text { Total Assets }}
$$

\section{Current Ratio}

The current ratio is not only the measure of the company's liquidity but also is a measure of the margin of safety that management maintains to allow for the inevitable unevenness in the flow of funds through the current asset and liability accounts (Anthony et al., 2010). The current ratio 
is the true indicator of liquidity since it considers the overall magnitude of each fund (Gitman, 2005). The ideal current ratio is 2:1 (Pandey, 2010; Chandra, 2008), but nowadays in the presence of high competition in the market several firms have tried to achieve a zero or even a negative. So, it can be very difficult to interpret the current ratio at present.

$$
\text { Current Ratio }=\frac{\text { Current Assets }}{\text { Current Liabilites }}
$$

\section{Net Profit Margin}

Net profit margin measures how much profit out of each sales dollar is left after all expenses are subtracted-that is, after all operating expenses, interest, and income tax are subtracted (Andrews, 2007:92).

$$
\text { Net Profit Margin }=\frac{\text { Net Income }}{\text { Net Sales }}
$$

\section{RESEARCH METHODS}

The methodology used in this study is quantitative research, this method used as a tool to measured data with various variables. The data used in this study is from (RMBA) PT. Bentoel Internasional Investama Annual Report on Five years before the acquisition and Five years after the acquisition. This study is used as a benchmark on the financial performance of the company before and after the acquisition.

The data on this study is based on the annual report published by RMBA from 2006-2010 (before acquisition) until 2011-2015 (after acquisition by
BAT), this study used annual report has been published year on year to describe the impact of the acquisition on financial performance. The variable used in this study is Current Ratio, Return on Equity, Return on Asset, Net Profit Margin. This study also used descriptive analysis to get more detail about any aspect of financial performance from every variable that has been used.

This study is to test if there is a difference in financial performance with one-sample t-test, which is the benchmark is two years before the acquisition. The level of significance $(\alpha)=0,05$ and tested criteria are shown below:

a. if Sig $t>0,05$, then Ho Accepted, which mean partially there is no significant difference in financial performance before and after the acquisition.

b. if Sig $\mathrm{t}<0,05$, then Ho Not Accepted, which mean partially there is a significant difference in financial performance before and after the acquisition.

\section{RESULTS AND DISCUSSIONS}

To evaluate financial condition \& financial performance of a company needed to check with Financial Ratio James C Van Horne (2001: 201). Based on the RMBA annual report from 2006-2015 tested with four ratios: Current Ratio, Return on Equity, Return on Asset, Net Profit Margin that shown in table 1.

Table 1. Ratio Pre-Acquisition and Post-Acquisition

\begin{tabular}{|c|c|c|c|c|c|}
\hline & Years & Current Ratio (\%) & ROE (\%) & ROA\% & Net Profit Margin (\%) \\
\hline \multirow{4}{*}{ Pre- acquisition } & 2006 & 160,73 & $12,63 \%$ & 7,09 & 4,86 \\
\cline { 2 - 6 } & 2007 & 353 & 17,78 & 8,9 & 5,3 \\
\cline { 2 - 6 } & 2008 & 247,83 & 14,62 & 5,75 & 4,03 \\
\cline { 2 - 6 } & 2009 & 265,92 & $-8,13$ & 0,58 & $-2,04$ \\
\cline { 2 - 6 } & 2010 & 249,99 & 10,82 & 4,75 & 2,46 \\
\hline \multirow{5}{*}{ post- acquisition } & 2011 & 111,96 & 13,62 & 5,45 & 3,04 \\
\cline { 2 - 6 } & 2012 & 164,27 & $-16,81$ & $-4,87$ & $-3,28$ \\
\cline { 2 - 6 } & 2013 & 117,87 & $-118,17$ & $-11,29$ & $-8,49$ \\
\cline { 2 - 6 } & 2014 & 100,17 & 163,13 & $-22,23$ & $-16,17$ \\
\cline { 2 - 6 } & 2015 & 220,34 & 52,04 & $-12,94$ & $-9,74$ \\
\hline
\end{tabular}




\section{Current Ratio One Sample T- Test}

From the result, it seems that the value of Sig $t<0,05$ which mean there is a significant different current ratio on financial performance before and after the acquisition. According to (Helfert, 1998) Current Ratio is a tool to test the protection level for a lender on short term loan that given to the company to fund the operational cost. According (Sawir, 2009) the lowest current ratio means there is liquidate problem but too high current ratio mean there are too many idle funds, this is effecting on lowering capability of the company generating income.

\section{ROE One Sample T-Test}

From the result, it can see that value of Sig t $(0,105)$ $>0,05$ on the pre-acquisition side and Sig t $(0,703)$ on post-acquisition side which mean there is no significant different ROE on financial performance before and after the acquisition. According (Kasmir 2012:204) Return on Equity is the ratio to measure net income after tax generates with equity. This ratio shows how efficient equity use, higher return on equity mean the better because the company not depending on liability as a source of fund and directly make a company in a strong position. According to Jumingan (2011: 245), return on equity used to measure how far a company generates net profit from equity only.

\section{ROA One Sample T-Test}

From the result, it can see that value of Sig $t(0,018)<0,05$ on the pre-acquisition part which means there is significant different ROA on financial performance. According (Machfoedz 1998) ROA describes that financial performance to generate income from an asset that uses for operating of the company. To generate income from the asset will impact on shareholder, higher ROA describes better financial performance and shareholder will earn more dividend from retained earnings, lower ROA means lower financial performance.

\section{NPM One Sample T- Test}

From the result, it can see that value of Sig $t(0,09)<0,05$ on the pre-acquisition part which means there is significant different NPM on financial performance. According (Kasmir 2013) Net Profit Margin is to measure profit by comparing profit after interest and tax compare with sales. The higher net profit margin means higher company productivity and profitability. Company liquidity that represents a company's cash used to determine the company's profit margin. If net profit margin decrease that means company profit decrease will decrease either.

According to One Sample Test that used in this study for all variable (Current Ratio, ROE, ROA, NPM) there is a significant difference shown by table 2.

One-Sample Statistics

\begin{tabular}{|l|c|c|c|c|}
\hline & N & Mean & Std. Deviation & Std. Error Mean \\
\hline preacquisition & 5 & 255,4940 & 68,34722 & 30,56580 \\
postacquisition & 5 & 142,9220 & 49,65699 & 22,20728 \\
\hline
\end{tabular}

One-Sample Test

\begin{tabular}{|c|c|c|c|c|c|c|}
\hline & \multicolumn{6}{|c|}{ Test Value $=0$} \\
\hline & \multirow[b]{2}{*}{$\mathbf{t}$} & \multirow[b]{2}{*}{$\mathbf{t}$} & \multirow[b]{2}{*}{ Sig. (2-tailed) } & \multirow{2}{*}{$\begin{array}{c}\text { Mean } \\
\text { Difference }\end{array}$} & \multicolumn{2}{|c|}{$95 \%$ Confidence Interval of the Difference } \\
\hline & & & & & Lower & Upper \\
\hline $\begin{array}{l}\text { preacquisition } \\
\text { postacquisition }\end{array}$ & $\begin{array}{l}8,359 \\
6,436\end{array}$ & $\begin{array}{l}4 \\
4\end{array}$ & $\begin{array}{l}, 001 \\
, 003\end{array}$ & $\begin{array}{l}255,49400 \\
142,92200\end{array}$ & $\begin{array}{r}170,6297 \\
81,2647\end{array}$ & $\begin{array}{l}340,3583 \\
204,5793\end{array}$ \\
\hline
\end{tabular}

Figure 1. Current Ratio with One Sample T-Test 
Wiwiek Mardawiyah Daryanto, Bramastra Purnomosidhi, Sarah Khairannisa / The Impact of Acquisition on Bentoel Internasional Investama Corporation Financial Performance / 144- 149

One-Sample Statistics

\begin{tabular}{|l|c|c|c|c|}
\hline & N & Mean & Std. Deviation & Std. Error Mean \\
\hline preacquisition & 5 & $\begin{array}{r}5,4140 \\
\text { postacquisition }\end{array}$ & $\begin{array}{r}3,11779 \\
10,26529\end{array}$ & $\begin{array}{l}1,39432 \\
4,59078\end{array}$ \\
\hline
\end{tabular}

One-Sample Test

\begin{tabular}{|c|c|c|c|c|c|c|}
\hline & \multicolumn{6}{|c|}{ Test Value $=0$} \\
\hline & \multirow[b]{2}{*}{$\mathbf{t}$} & \multirow[b]{2}{*}{$\mathbf{t}$} & \multirow[b]{2}{*}{ Sig. (2-tailed) } & \multirow{2}{*}{$\begin{array}{c}\text { Mean } \\
\text { Difference }\end{array}$} & \multicolumn{2}{|c|}{$95 \%$ Confidence Interval of the Difference } \\
\hline & & & & & Lower & Upper \\
\hline $\begin{array}{l}\text { preacquisition } \\
\text { postacquisition }\end{array}$ & $\begin{array}{r}3,883 \\
-1,999\end{array}$ & $\begin{array}{l}4 \\
4\end{array}$ & $\begin{array}{l}, 018 \\
, 116\end{array}$ & $\begin{array}{r}5,41400 \\
-9,17600\end{array}$ & $\begin{array}{r}1,5427 \\
-21,9220\end{array}$ & $\begin{array}{l}9,2853 \\
3,5700\end{array}$ \\
\hline
\end{tabular}

Figure 3. ROA Ratio with One Sample T-Test

One-Sample Statistics

\begin{tabular}{|c|c|c|c|c|}
\hline & $\mathbf{N}$ & Mean & Std. Deviation & Std. Error Mean \\
\hline $\begin{array}{l}\text { preacquisition } \\
\text { postacquisition }\end{array}$ & $\begin{array}{l}5 \\
5\end{array}$ & $\begin{array}{r}2,9220 \\
-6,9280\end{array}$ & $\begin{array}{l}2,97797 \\
7,21856\end{array}$ & $\begin{array}{l}1,33179 \\
3,22824\end{array}$ \\
\hline
\end{tabular}

One-Sample Test

\begin{tabular}{|c|c|c|c|c|c|c|}
\hline & \multicolumn{6}{|c|}{ Test Value $=0$} \\
\hline & \multirow[b]{2}{*}{$\mathbf{t}$} & \multirow[b]{2}{*}{$\mathbf{t}$} & \multirow[b]{2}{*}{ Sig. (2-tailed) } & \multirow{2}{*}{$\begin{array}{c}\text { Mean } \\
\text { Difference }\end{array}$} & \multicolumn{2}{|c|}{$95 \%$ Confidence Interval of the Difference } \\
\hline & & & & & Lower & Upper \\
\hline $\begin{array}{l}\text { preacquisition } \\
\text { postacquisition }\end{array}$ & $\begin{array}{r}2,194 \\
-2,146\end{array}$ & $\begin{array}{l}4 \\
4\end{array}$ & $\begin{array}{l}, 093 \\
, 098\end{array}$ & $\begin{array}{r}2,92200 \\
-6,92800\end{array}$ & $\begin{array}{r}-, 7756 \\
-15,8910\end{array}$ & $\begin{array}{l}6,6196 \\
2,0350\end{array}$ \\
\hline
\end{tabular}

Figure 4. Net Profit Margin Ratio with One Sample T-Test

One-Sample Statistics

\begin{tabular}{|c|c|c|c|c|}
\hline & $\mathbf{N}$ & Mean & Std. Deviation & Std. Error Mean \\
\hline $\begin{array}{l}\text { preacquisition } \\
\text { postacquisition }\end{array}$ & $\begin{array}{l}5 \\
5\end{array}$ & $\begin{array}{r}9,5440 \\
18,7620\end{array}$ & $\begin{array}{r}10,21175 \\
102,45941\end{array}$ & $\begin{array}{r}4,56683 \\
45,82124\end{array}$ \\
\hline
\end{tabular}

One-Sample Test

\begin{tabular}{|c|c|c|c|c|c|c|}
\hline & \multicolumn{6}{|c|}{ Test Value $=0$} \\
\hline & \multirow[b]{2}{*}{$\mathbf{t}$} & \multirow[b]{2}{*}{$\mathbf{t}$} & \multirow[b]{2}{*}{ Sig. (2-tailed) } & \multirow{2}{*}{$\begin{array}{c}\text { Mean } \\
\text { Difference }\end{array}$} & \multicolumn{2}{|c|}{$95 \%$ Confidence Interval of the Difference } \\
\hline & & & & & Lower & Upper \\
\hline $\begin{array}{l}\text { preacquisition } \\
\text { postacquisition }\end{array}$ & $\begin{array}{r}2,090 \\
, 409\end{array}$ & $\begin{array}{l}4 \\
4\end{array}$ & $\begin{array}{l}, 105 \\
, 703\end{array}$ & $\begin{array}{r}9,54400 \\
18,76200\end{array}$ & $\begin{array}{r}-3,1356 \\
-108,4582\end{array}$ & $\begin{array}{r}22,2236 \\
145,9822\end{array}$ \\
\hline
\end{tabular}

Figure 2. ROE Ratio with One Sample T-Test

Table 2. Statistic Data Financial Ratio RMBA

\begin{tabular}{|c|c|c|c|c|c|}
\hline No & Financial Ratio & Sig. & Alfa $(\boldsymbol{\alpha})$ & Ho Accepted/ Rejected & Other Information \\
\hline 1 & Current Ratio & 0,003 & 0,05 & Ho Rejected & Significant \\
\hline 2 & ROE & 0,703 & 0,05 & Ho Accepted & No significant \\
\hline 3 & ROA & 0,018 & 0,05 & Ho Rejected & Significant \\
\hline 4 & NPM & 0,098 & 0,05 & Ho Rejected & Significant \\
\hline
\end{tabular}




\section{CONCLUSIONS}

According to the research which has been done, it can be concluded three variables, which are Current Ratio, Return on Assets and Net Profit Margin that has a significant impact on postacquisition at RMBA. While the other variable, which is Return on Equity does not have a significant impact on post-acquisition. This relation shows that the acquisition of a tobacco company does significantly affect financial performance.

Also, acquisition of RMBA by BAT has a big impact of decreasing the financial performance of a company in the last five years after the acquisition, furthermore financial performance in pre-acquisition is much better and there is a positive relation between Current Ratio, Return on Assets and Net Profit Margin with RMBA financial performance. Regarding the recommendation for future research, the study can be more accurate if increasing the number of samples of the companies, extending the years of samples, and added more variable ratio.

\section{REFERE N C ES}

Anthony, R.N., Hawkins D.F., Merchant K. A., 2010, Accounting text and cases, Tata McGraw Hill Education Pvt Limited, New Delhi.

Andrew, Joseph D. 2007. Financial Management: Principle and Practice, 4th edition. United State: Freeload Press.

Brigham, Eugene F. \& Houston, Joel F. 2001. Fundamentals of Financial Management, Eight Edition. Jakarta: Erlangga.

Gitman.L.J., 2005, Principles of managerial finance, Harper and Row Publishers, New York. Helfert, E.A., 1998, Teknik Analisis Keuangan. Jakarta: Erlangga.

Kasmir. 2012, Analisa Laporan Keuangan. Jakarta: PT. Raja Grafindo Persada

Kasmir. 2013, Analisis Laporan Keuangan, Rajawali Pers, Jakarta.

Khrawish, H.A. 2011 "Determinants of Commercial Banks Performance: Evidence from Jordan". International Research Journal of Finance and Economics, ISSN 1450-2887 Issue 81.

Jumingan 2011. Analisis Laporan Keuangan. Jakarta: Bumi Aksara

Moin, Abdul. 2003. Merger, Akuisisi dan Divestasi. Jilid 1. Yogyakarta, Ekonisia. Priyatno, Dwi. 2012. Cara Kilat Belajar Analisis Data Dengan SPSS 20. Andi: Yogyakarta. Rao, K. \&Sanker, K. 1997 Takeover as a strategy of turnaround. Mumbai: UTI.

Sawir, A. 2009, Analisa Kinerja Keuangan dan Perencanaan keauangan Perusahaan, PT. Gramedia Pustaka Utama, Jakarta.

Suparwoto. 1990. Akuntansi Keuangan Lanjutan: Laporan Keuangan Konsolidasi Pendekatan terpadu. Yogyakarta: BPFE Yogyakarta.

IDX. Annual Report RMBA Bentoel Internasional Investama. http://www.idx.co.id/ Accessed on 20 March 2018. 